International Journal of Civil Engineering and Technology (IJCIET)

Volume 10, Issue 03, March 2019, pp. 1728-1738. Article ID: IJCIET_10_03_169

Available online at http://www.iaeme.com/ijciet/issues.asp?JType=IJCIET\&VType=10\&IType=03

ISSN Print: 0976-6308 and ISSN Online: 0976-6316

(C) IAEME Publication

Scopus Indexed

\title{
THE CALCULATION OF THE UPPER \& LOWER COMPONENTS OF THE NEW RAILWAY ROAD IN DEAD LINES REACTIVATION IN BABAT-JOMBANG AS A CROSS SUPPORT
}

\author{
Dadang Supriyatno* \\ Faculty of Engineering Surabaya State of University, Indonesia, Kampus Ketintang Unesa, Jl. \\ Ketintang Surabaya 60231, East Java Indonesia \\ Muhammad Ikhsan Setiawan \\ Program Studi Teknik Sipil, Universitas Narotama, Surabaya, Indonesia \\ *Corresponding author
}

\begin{abstract}
Railways public transport play important roles in Indonesia in which it becomes one mode of national transportation system with bulk freight characteristics and it contains more advantages compared with other transport modes. The research aimed to know the rail class calculation on the reconstruct of line tripe-stubs based on the operation of the train and its load. Besides, this study also aimed to test the upper components to know the class of the railway by using UIC (Union International Railway) and PD 10 (Peraturan Dinas 10). Based on the result of the planning calculation the reconstruction of rail roads from Babat to Jombang, it was found that a new rail road which include rails type 50, concrete pads, ballast and sub ballast, and track from Babat to Jombang, later it can be passed by using a locomotive type CC 202 based on the calculation of the rail class by using Passing Tonage the result is UIC 6. Meanwhile, based on the Peraturan Dinas 10 possessed by PT. Kereta Api, and the locomotive's load axle and speed, the rail class on that line is planned to use II rail class.
\end{abstract}

Keywords: Mass transport, transport infrastructure, the rail network.

Cite this Article: Dadang Supriyatno and Muhammad Ikhsan Setiawan, The Calculation of the Upper \& Lower Components of the New Railway Road in Dead Lines Reactivation in Babat-Jombang as a Cross Support, International Journal of Civil Engineering and Technology, 10(3), 2019, pp. 1728-1738.

http://www.iaeme.com/IJCIET/issues.asp?JType=IJCIET\&VType=10\&IType $=03$ 


\section{INTRODUCTION}

The success of development is strongly influenced by the role of transportation as an artery of political life, economic, social, cultural, and Defense-Security[1][2][3]. In this regard, railways as one mode of transportation in the national transportation system has bulk freight characteristics and some advantages[4][5].

The provincial Government of East Java in their planning on transportation infrastructure development[6], will apply the bulk transportation of rail-based by establishing or reviving a rail line integrated with network rail road turning to the rest of the territory within a radius of 100 kilometres west of Surabaya. As for the rail network planping rotation, it will soon be developed in a way to revive the rail line from Babat to Jombang City[7].

With a revived track from Babat-Jombang, it is expected that it will contribute particularly to a reduce congestion linkway South cross by Nothern cross and also to minimize congestion throughout the $100 \mathrm{~km}$ area from Surabaya that is the commuter rail line that runs from Surabaya-Mojokerto-Jombang-Babat-Gresik and Lamongan-return to Surabaya or vice versa. On the commuter line, it will serve the transport of passengers and goods passing through the corridor commuter rail operations[8].

\section{METHOD}

To obtain the data and information required in the activities of this research, the study employs methods as follows:

a. preparation phase: preliminary preparation stages is in the implementation of the study in the form of an inventory survey, data collection and other supporting and existing studies.

b. Data collection Stage: that is by obtaining the required data in the analysis of technical studies of rail road Babat-Jombang line reactivation.

c. The Analysis and planning stages of the development of the railway network of Babat-Jombang that will result in the Analysis and planning of the development of emplasemen and its infrastructure, as a follow-up to the development of railways in Babat-Jombang line.

\section{RESULT AND DISCUSSION}

\subsection{Traffic Classification in the UIC}

In the maintenance or enhancement of rail roads affected by the magnitude as follows:

- A daily passenger train Tonnage

- The tonnage of freight train and propulsion

- The pressure of the axle

- Speed

On cross Babat-Stubs, it will improve their capacity, the data decription is as follows:

The frequency of trains cross Babat-Jombang is estimated as follows:

$\begin{array}{ll}\text { Passenger train } & =6 \mathrm{KA} / \text { day } \\ \text { Freight train } & =12 \mathrm{KA} / \text { day } \\ \text { Commuter train } & =8 \mathrm{KA} / \text { day } \\ \text { It is estimated }(\mathrm{D}) & =8 \mathrm{KA} / \text { day }\end{array}$


The Calculation of the Upper \& Lower Components of the New Railway Road in Dead Lines Reactivation in Babat-Jombang as a Cross Support

Frequency $=46 \mathrm{KA} /$ day

Stam formation is as follows:

The number of a series of passenger train each $=7$ trains

The number of a series of freight train each $=12$ trains

The number of a series of commuter train each $=8$ trains

The number of one of the other train sets $(\mathrm{D})=6$ train

The number of sets/day:

Passenger Train $=18 \times 7=126$ train

Freight train $\quad=12 \times 12=144$ trains

Commuter Train $=8 \times 8=64$ trains

It is estimated $(D)=9 \times 6=54$ trains

The number of arrangements $=388 /$ train carriages $/$ day

The weight of the Series:

Passenger Trains

$126 \times 35$ Ton $=4410$ Tons $/$ day

$64 \times 35$ Ton $=2240$ Tons/day

$54 \times 35$ Ton $=2200$ Tons $/$ day

Amount $=8540$ Tons/day

Freight Train

$144 \times 35$ Ton $=3300$ Tons/day

Tonnase passengers and trains

$=8540$ tons $/$ day $(\mathrm{Tp})$

Tonnase barng and cars daily

$=3300$ tons $/$ day $(\mathrm{Tb})$

Tonnase Locomotives (T1)

locomotive used type C.C $202=108$ Tons

Coefficient of load and Traffic Quality

$\mathrm{KB}=1.15$ (For a load axle s. $\mathrm{d} 20$ tons)

$\mathrm{S}=1.1$ (For road rail passenger TRAIN with $\mathrm{V} \max \leq 200 \mathrm{~km} / \mathrm{hour}$ )

$\mathrm{K} 1=1.4$

$\mathrm{TE}=\mathrm{Tp}+(\mathrm{Kb} \times \mathrm{Tb})+(\mathrm{K} 1 \times \mathrm{T} 1)$

$=8540+(5000 \times 1.15)+(1.4 \times 108)$

$=8540+5796+151$

$=14487$ Tons/day

Passing Tonnage:

$$
\begin{aligned}
\mathrm{T} & =360 \times \mathrm{S} \times \mathrm{TE} \\
& =360 \times 1.1 \times 14487
\end{aligned}
$$




$$
=5.736 .852 \text { tonnes/year }
$$
UIC 7

Then, cross Babat-Jombang includes in III class (as PD 10) and entry requirement of the

\subsection{The Renewing of The Under Construction Building Implementation Method}

With the renewal of construction including thick pads and a thick ballast larger than the old construction, It will be open space to new ballast and sub ballast place (layers of sand), given the high construction of the new rail road from the head rail (KR) to the sub ballast with the minimum $\pm 82.50 \mathrm{~cm}$.

To give you an idea of the position of the old rail road R. 25 with the new position R. 50, the difference of rail road high construction update can be seen in figure 1 below:

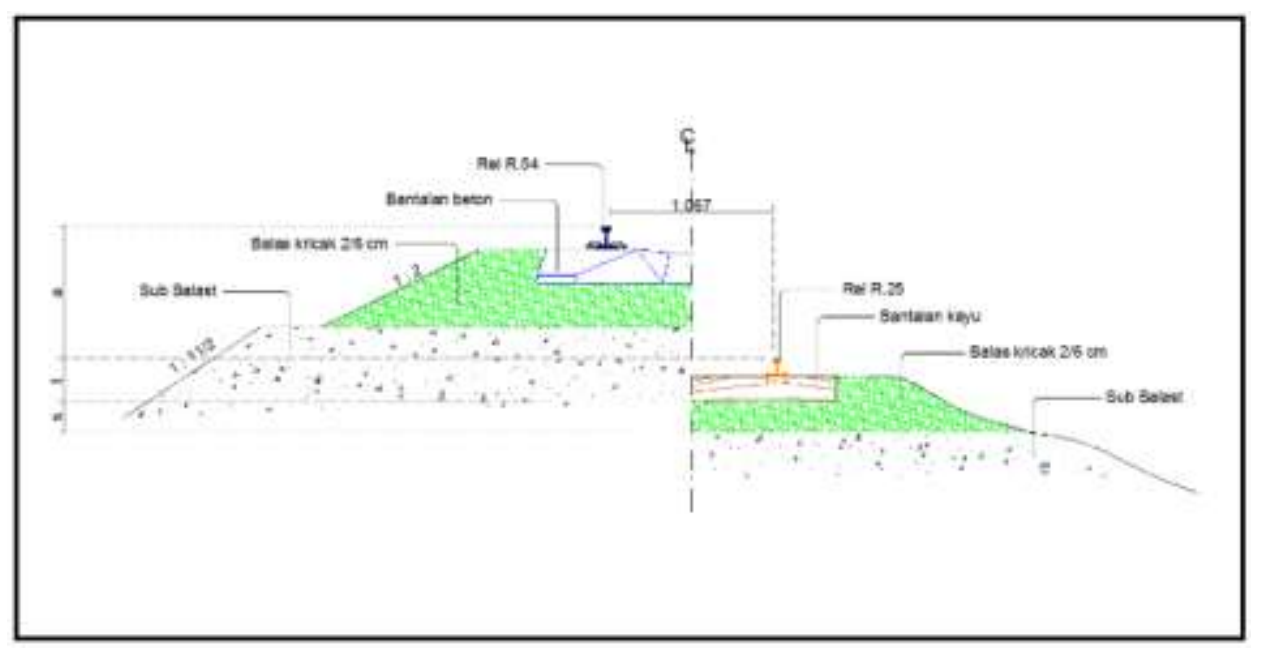

Figure 1 Height Difference of Existing Track and New Track Construction

\subsection{The Calculation of Rail Road Construction Updates of Babat-Tuban}

By analyzing the standard class of rail roads in the rules of the service (PD) 10, as described above, then the provisions are as follows:

The class path supporting cross Babat-Tuban planned class II

$\mathrm{V}$ maks $\quad=100 \mathrm{~km} / \mathrm{hour}$

- $\mathrm{d} 1=30 \mathrm{~cm}$

- $\mathrm{b} \quad=140 \mathrm{~cm}$

- $\mathrm{c} \quad=225 \mathrm{~cm}$

- $\mathrm{k} 1=240 \mathrm{~cm}-270 \mathrm{~cm}($ taken $=270 \mathrm{~cm})$

- $\mathrm{d} 2=15 \mathrm{~cm}-50 \mathrm{~cm}($ taken $=15 \mathrm{~cm})$

- $\mathrm{e} \quad=22 \mathrm{~cm}$

- $\mathrm{k} 2=325 \mathrm{~cm}$

It can be seen in the list of classification classes of railroad according rules of the service (PD) 10. To give an idea of the height of construction after the improvement of the upper and lower construction, it is shown as follows :

The Upper Construction:

Height R.50 rail $\quad=15.00 \mathrm{~cm}($ new $)$ 
The Calculation of the Upper \& Lower Components of the New Railway Road in Dead Lines Reactivation in Babat-Jombang as a Cross Support

Thick Pad $\quad=0.50 \mathrm{~cm}$

Thick concrete pads $\quad=22.00 \mathrm{~cm}$

The Lower Construction :

Thickness of ballast $\quad=30.00 \mathrm{~cm}$

the Sub-ballast $\quad=15.00 \mathrm{~cm}$

amount $\quad=82,50 \mathrm{~cm}$

The high of construction before any updates (existing track), is:

The Upper Construction:

Height R.50 rail $\quad=9.30 \mathrm{~cm}$ (aus $7 \mathrm{~mm}$ )

Thickness of base plate $\mathrm{a}$ or $\mathrm{b} \quad=1.50 \mathrm{~cm}$

Thickness Bearing wood $\quad=12.00 \mathrm{~cm}$

The Lower Construction :

Thickness of ballast $\quad=20.00 \mathrm{~cm}$ (thick soil mix)

the Sub-ballast $\quad=15.00 \mathrm{~cm}$

amount $=57,80 \mathrm{~cm}$.

The size of the Upper and Lower of the building

Calculation of the volume of a unit to new track:

Stone broke ballast

$=(1.40+2.25)(0.22+0.30)-10 / 6 \times 2 \times 0,22 \times 0,23)+20 \%$

$=2,07 \approx 2.10 \mathrm{~m}^{3}$ (maximum)

the Sub-ballast

$=[(2.70+3.25)(0.15+0.22)-(25 \times 0,22,3)]+20 \%$

$=1.781 .80 \approx \mathrm{m}^{3}$ (minimum)

Calculation of tension in the upper and lower constructions of the rail roads.

Rail $=540$ new Type $\mathrm{R}$

$\mathrm{P} \quad=50.00 \mathrm{Kg} / \mathrm{m}^{\prime}$

$\mathrm{a}=0.60 \mathrm{~m}$

$\mathrm{Wx} \quad=270 \mathrm{~cm}^{3}$

$$
\delta \quad=\frac{0,40}{1+\mathrm{Cx}}+\frac{\mathrm{P}}{\mathrm{a}}
$$

According to verein factor coefficient of speed of the plan is as follows

$$
\mathrm{CX}=\frac{V^{2}}{30.000}
$$

Plans to speed $110 \mathrm{~km} /$ hour rail road class II according to, then,

$$
\begin{gathered}
C x=\frac{V^{2}}{30.000} \\
\delta=\frac{0,40}{1+0,33}+\frac{50}{0.60}=\frac{0,40}{1,33} \times 83,33 \\
=\frac{33,33}{1,33}=25,06 \text { Ton }
\end{gathered}
$$


Thus, for the use of railway axle load of 18 tons of $\mathrm{r}$. 50 new ones are able to focus on cross axle load of Babat-Jombang. So cross with Rails R 50 is reasonably safe.

Cross Babat-Jombang is expected to be traversed to all locomotives operating in Java island, including the type of CC 202, it will review the upper and lower construction components rail on the cross with the road rail renewal plan.

Where:

Axle loads operating = 18 tons (type of locomotive CC 202), as figure 2 below

Axle distance

$$
=1.6 \mathrm{~m}
$$

Concrete bearing distance $=0.60 \mathrm{~m}$

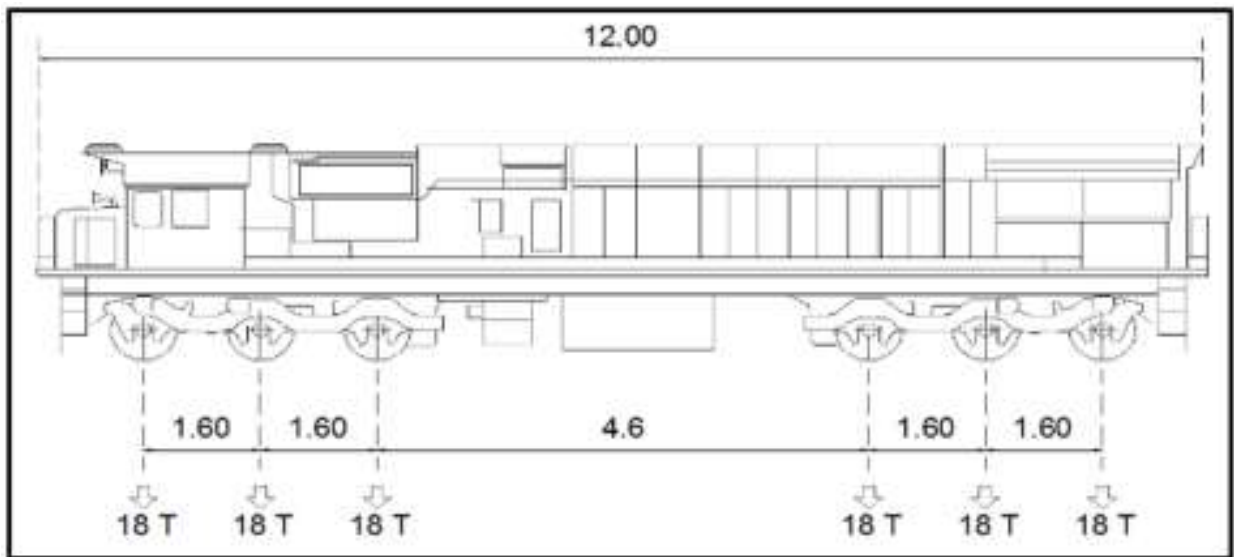

Figure 2 The Dimensions of Locomotive Type CC 202

Concrete pads size $=$

Top width $\quad: 20.00 \mathrm{~cm}$

Bottom width $: 23.00 \mathrm{~cm}$

$\frac{V^{2}}{30.000}$ Height $\quad: 22.00 \mathrm{~cm}$

Speed coefficient $=1+$

So :

$$
\begin{gathered}
\frac{18+18}{2} \delta=\quad=18 \text { ton } \\
\mathrm{n}=\frac{\mathrm{d}}{\mathrm{a}}=\frac{1,6}{0,6}=2,67 \\
\frac{\delta}{\mathrm{n}}=\frac{18}{2,67}=6,74 \text { ton }
\end{gathered}
$$

If the axle is a combination of two profitable speed $110 \mathrm{~km} / \mathrm{h}$, then the largest bearing pressure becomes:

$$
\begin{aligned}
\mathrm{D}_{\max } \quad= & 6,74\left(1+\frac{10.000}{30.000}\right) \\
= & 6,74(1+0,33) \\
& =8,96 \text { ton } \approx 8.960 \mathrm{~kg}
\end{aligned}
$$

Wide under concrete pads

$$
=22.00 \times 200,00=4.600 \mathrm{~cm} 2
$$


The Calculation of the Upper \& Lower Components of the New Railway Road in Dead Lines Reactivation in Babat-Jombang as a Cross Support

So the pressure of ballast under the bearing becomes:

$$
\sigma b=\frac{9.346}{4600}=2,05 \mathrm{~kg} / \mathrm{cm}^{2}<\mathrm{PD} 10=2,25 \mathrm{~kg} / \mathrm{cm}^{2}
$$

For a thick ballast on concrete pad is $30 \mathrm{~cm}$ with a slope angle of $60^{\circ}$ drilling as reflected in figure 3 below, So the pressure of sub ballast become:

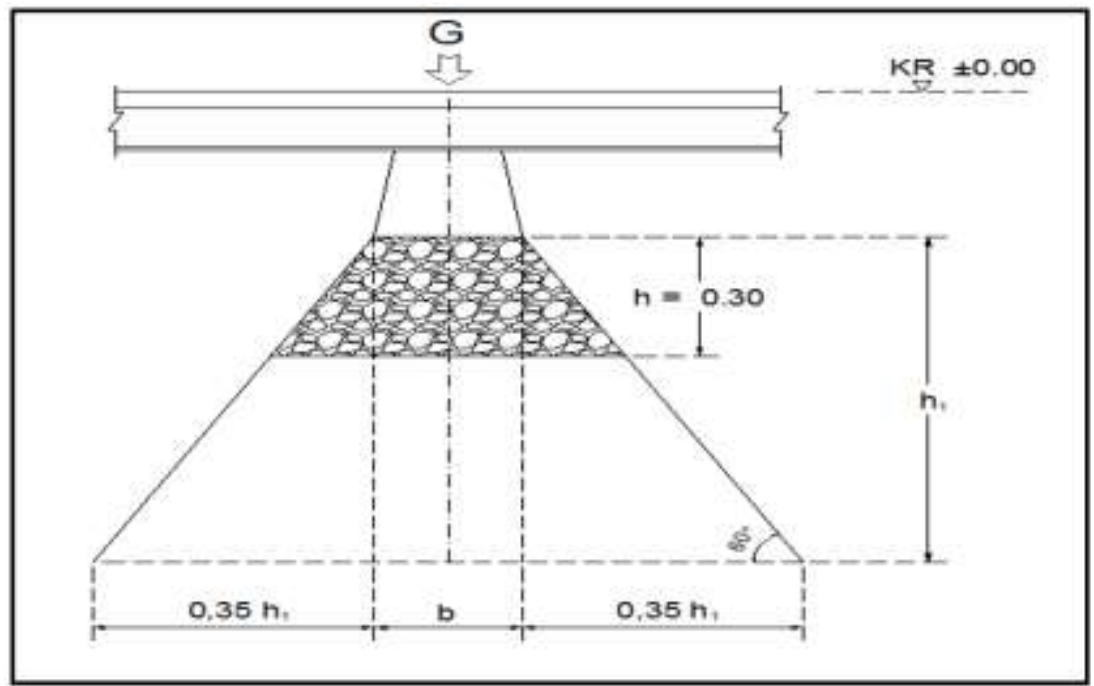

Figure 3 Spread the Burden of The Railway Lower Construction

$$
\begin{gathered}
\sigma \pi=\frac{\mathrm{b}}{\mathrm{b}+0,7 \mathrm{l}} \times \sigma \mathrm{b} \\
\sigma \pi=\frac{23}{23+0,7(30)} \times 1,95 \\
=\frac{44,85}{44} \\
=1.10 \mathrm{~kg} / \mathrm{cm}^{2}=10 \mathrm{PD}<1.25 \mathrm{~kg} / \mathrm{cm}^{2} \text { (safe) }
\end{gathered}
$$

When in cross posted with a thickness of $25 \mathrm{~cm}$, then :

$$
\begin{gathered}
\sigma \pi=\frac{47,15}{40,50} \\
=1.16 \mathrm{~kg} / \mathrm{cm}^{2}=10 \mathrm{PD}<1.25 \mathrm{~kg} / \mathrm{cm}^{2}(\text { safe })
\end{gathered}
$$

For the thickness of ballast $20 \mathrm{~cm}$ :

$$
\begin{gathered}
\sigma \pi=\frac{44,85}{44} \\
=1.27 \mathrm{~kg} / \mathrm{cm}^{2}>\text { PD } 10=1.25 \mathrm{~kg} / \mathrm{cm}^{2}
\end{gathered}
$$

(not quite safe)

By looking at the above calculation with a thickness of ballast which was just $25 \mathrm{~cm}$ the rail road, it can be assumption that is already safe enough, but when the planned for the thickness of the ballast under the pads of $20 \mathrm{~cm}$, it is not secure.

With a loading axle placed at the line of Babat-Jombang becoming 18 tons, it was investigated whether the pressure of rail that occur from R.54 would not be exceeded. 
If $\sigma=1600 \mathrm{~kg} / \mathrm{cm} 2$, it was be investigated the pressure occuring for middle and end axle by using approach formula: Verein and Dresien.

\subsubsection{For the middle axle.}

$$
\begin{gathered}
\sigma \mathrm{a} \quad=\frac{12 \times m \times n-7(m+n)+4}{16[3 \times m \times n-(m+n)]} \times \frac{g \times a}{W x} \\
\mathrm{~m} \quad=\frac{160}{60}=2,67 \times \mathrm{Wx}=270 \mathrm{~cm}^{3} \\
\mathrm{n} \quad=\frac{460}{60}=7,67 \\
\mathrm{~K} \quad=1+\frac{V 2}{30.000}=1+\frac{10.000}{30.000}= \\
\mathrm{g} \quad=\frac{G}{2}=\frac{18}{2}=9000 \mathrm{~kg} \\
=\frac{12 \times 2,67 \times 7,67-7(2,67+7,67)+4}{16[3 \times 2,67 \times 7,67-(2,67+7,67)]} \times 2000 \\
=\frac{245,75-72,38+4}{16(61,44-10,34)} \times 2000 \\
=\frac{177,37}{817,6} \times 2000 \\
=433,87 \mathrm{~kg} / \mathrm{cm}^{2}<\bar{\sigma}=1600 \mathrm{~kg} / \mathrm{cm}^{2}(\mathrm{safe})
\end{gathered}
$$

\subsubsection{The end axle}

$$
\begin{gathered}
\sigma \mathrm{u} \quad=\frac{12 \times n-7}{16(3 n-1)} \times \frac{g \times a}{W x} \mathrm{~kg} / \mathrm{cm}^{2} \\
=\frac{(12 \times 7,67)-7}{16(3 \times 7,67-1)} \times \frac{9000 \times 60}{270} \\
=\frac{85,04}{352,16} \times 2000 \\
=482,96 \mathrm{~kg} / \mathrm{cm}^{2}<\bar{\sigma}=1600 \mathrm{~kg} / \mathrm{cm}^{2} \text { (safe) }
\end{gathered}
$$

Conclusion

New rail R 50 put on the cross Babat-Jombang was eligible and worthy to be used on that cross.

\subsection{The Determination of The Trace Line Direction of Babat-Jombang}

The Determination of the trace line Direction of Babat-Jombang are divided based on some segments, such as:

\subsubsection{Babat-Kedungpring Segment}

For arbitration, the line for Babat-Kedungpring segment is shown in figure $\mathbf{4}$ below 
The Calculation of the Upper \& Lower Components of the New Railway Road in Dead Lines Reactivation in Babat-Jombang as a Cross Support

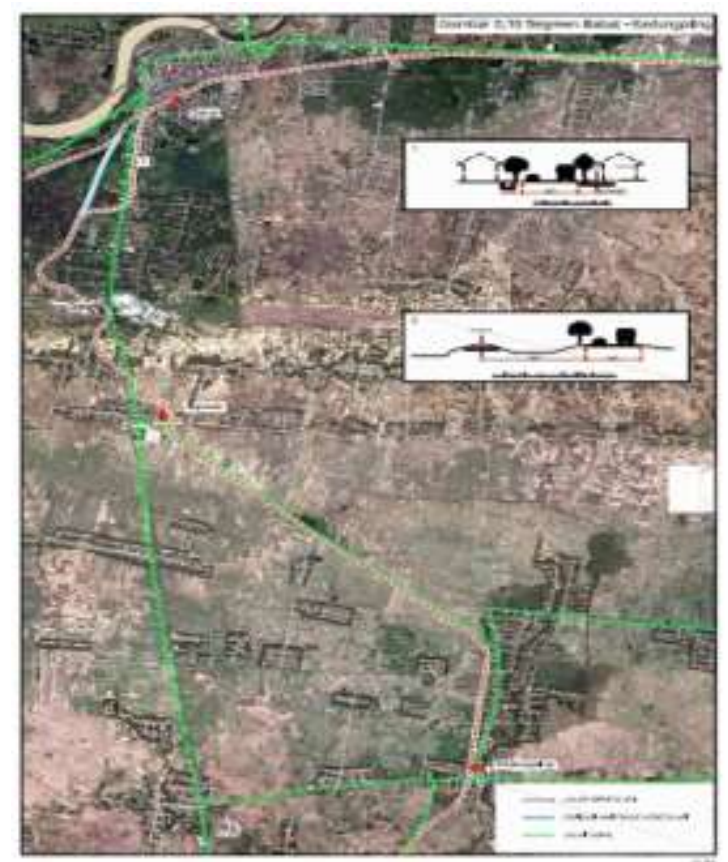

Figure 4 The segment of Babat-Kedungpring

\subsubsection{Kedungpring-Ngimbang segment}

For arbitration, the line for Kedungpring-Ngimbang segment is shown in figure 5 below

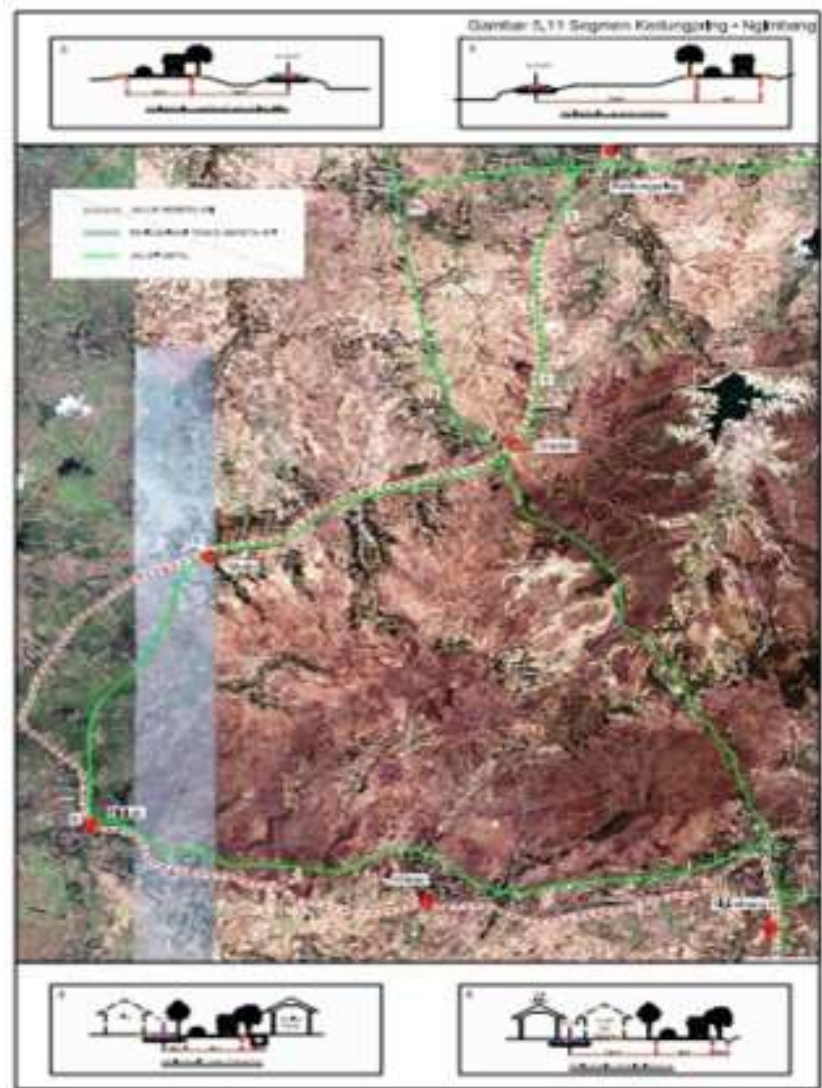

Figure 5 The segment of Kedungpring-Ngimbang 


\subsubsection{Ngimbang-Ploso Segment}

For arbitration, the line for Ngimbang-Ploso segment is shown in figure $\mathbf{6}$ below

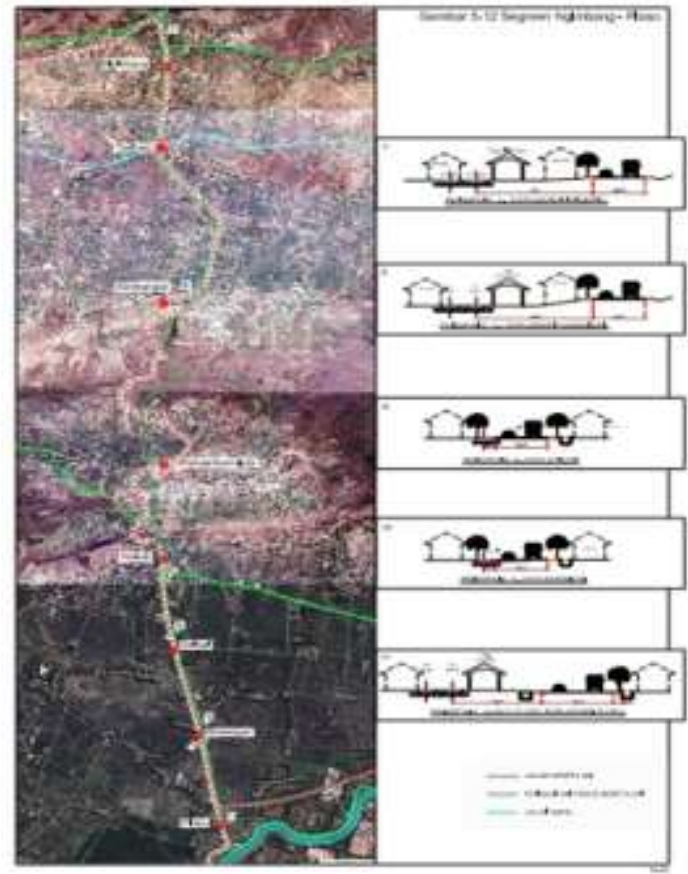

Figure 6 The segment of Ngimbang-Ploso

\subsubsection{Ploso-Jombang Segment}

For arbitration, the line for Ploso-Jombang segment is shown in figure 7 below

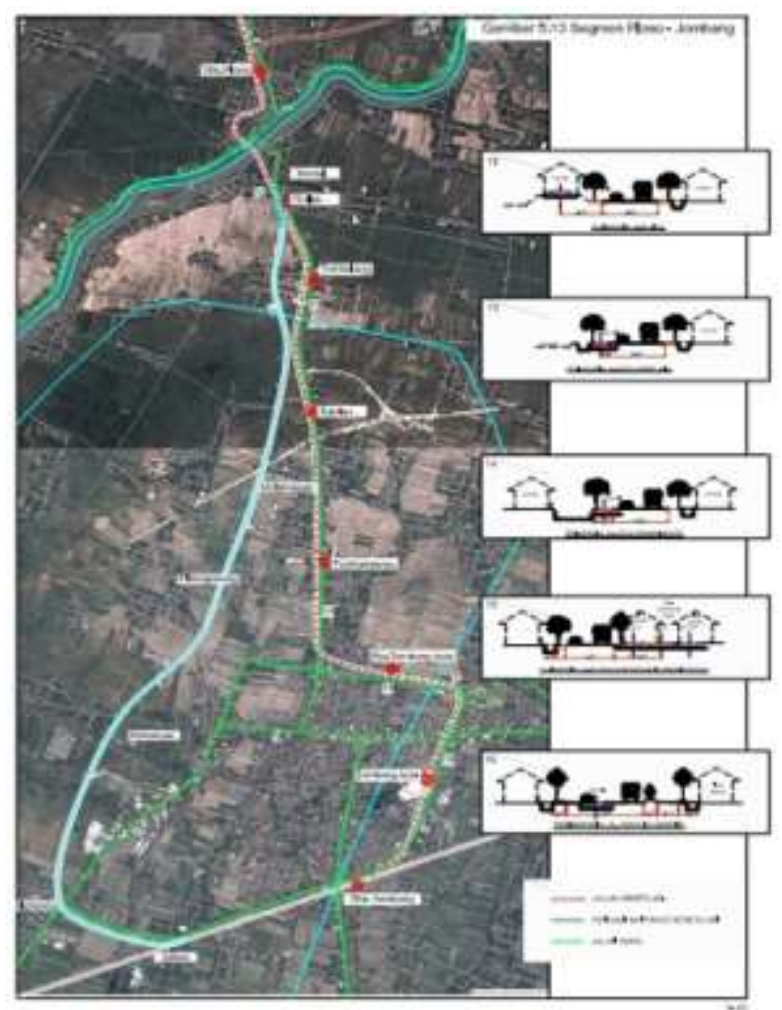

Figure 7 The segment of Ploso-Jombang 
The Calculation of the Upper \& Lower Components of the New Railway Road in Dead Lines Reactivation in Babat-Jombang as a Cross Support

\section{CONCLUSION}

\subsection{Based on the results and discussion, it can be concluded that:}

a. The upper and lower construction was able to pass with an 18 Ton axle load in accordance with the calculation of the PD 10 or in accordance with the UIC Method passing tonnage. Based on the results of the calculation of tBabat-Jombang entered to UIC category 7.

b. It needs that the new rail road construction includes a type of rail, rail pads, rail fastening, ballast and sub ballast that would be crossed by the locomotive type CC 202 by using type of rails $R 50$

\section{REFERENCES}

[1] C. Esveld, "Modern Railway Track, 2nd Editon," Delft Univ. Technol., 2001.

[2] S. A. P. Rosyidi, "Rekayasa Jalan Kereta Api.” LP3M UMY, 2015.

[3] R. I. Presiden, "Peraturan Pemerintah Republik Indonesia Nomor 56 tahun 2009 tentang Penyelenggaraan Perkeretaapian.” Jakarta, 2009.

[4] J. S. Mundrey, Railway track engineering. Tata McGraw-Hill Education, 2009.

[5] T. G. Crainic and G. Laporte, "Planning models for freight transportation," Eur. J. Oper. Res., vol. 97, no. 3, pp. 409-438, 1997.

[6] R. Indonesia and M. P. R. Ketetapan, "Nomor," MPR/2003 tentang Peninjauan Terhadap Mater. dan Status Huk. Ketetapan Majelis Permusyawaratan Rakyat Sementara dan Ketetapan Majelis Permusyawaratan Rakyat Tahun, 1960.

[7] D. NUR CAHYO, "PERKEMBANGAN TRANSPORTASI KERETA API DI KABUPATEN LAMONGANTAHUN 1899-1932,” Avatara, vol. 5, no. 1, 2016.

[8] N. B. Susanto and I. Muthohar, "Analisis Distribusi Beban Kereta Api Pada Konstruksi Timbunan Jalur Kereta Api.” Yogyakarta: Universitas Gadjah Mada, 2015. 